\title{
Driving Factor of Consumer Preferences for Food and Beverages Product Enriched with Green Tea Powder
}

\author{
Lucyana Trimo $^{1, *}$, Yosini Deliana ${ }^{1}$, Sri Fatimah ${ }^{1}$,Mai Fernando Nainggolan ${ }^{1}$, \\ Mohamad Djali ${ }^{2}$ \\ ${ }^{1}$ Department of Agricultural Socio-Economics, Faculty of Agriculture, UNPAD; ${ }^{2}$ Department of Food Industry Technology, Faculty of \\ Agricultural Science Technology, UNPAD
}

Received: February 27, 2021; Revised: May 18, 2021; Accepted: July 19, 2021

\begin{abstract}
In general, people have known tea as a refreshing and healthy beverage product. Green tea powder is one of the raw materials for the meter industry which contains a lot of polyphenols and antioxidants beneficial for health. The purpose of this study was to evaluate consumer preferences for a variety of food and beverage products containing green tea powder. The research method used is a positive approach and descriptive statistics. Primary data and information were collected from 200 respondents through a survey using well-structured questionnaires and interviews. Organoleptic test (hedonic or preference test) is a technique used in testing the acceptability of various food and beverage products. The hedonic scale is used to determine the level of preference, which is then analyzed using the same multi-attribute ideal number as the Semantic Differential Method. The results showed that $53 \%$ of respondents liked the taste of products enriched with green tea powder. Tea lattes, cupcakes, and layer cakes are products that are not favored. They have a preference value of 1.79 , 1.48, 1.48, respectively. This means that the product has a dislike attribute, especially in taste, while bread is the most preferred product with a preference value of 0.31 . In increasing consumer preferences for food and beverage products enriched with green tea powder, there are at least four development priorities that must be carried out, namely determining the right combination of product composition, improving texture, competitive prices, being more attractive and good, environmentally friendly packaging, create the uniqueness of product.
\end{abstract}

Keywords: green tea powder, driving factor, food and beverages product, product improvement

\section{Introduction}

People in Indonesia have recognized tea as a refreshing and healthy drink in various forms (i.e. black tea, green tea, Oolong tea, fragrant tea and white tea, which are very popular lately). Globally, tea itself is no longer a food ingredient that is processed only for beverages, but has become an ingredient (intermediate product) that can be added to various food and beverage products, cosmetics, and biopharmaceuticals. In line with Hugard Patil (2017), consumers around the world are increasingly paying attention to the nutrition, health, and quality of their tea products. Environmental and health awareness is increasingly reflected through increasing consumer interest in the consumption of branded tea. Oikarinen et al. (1998) in Hasan (2020) stated that skin therapy is through combination therapy such as the use of moisturizers, antibiotics, antihistamines, and corticosteroids to treat skin inflammation to improve the function of the changed skin barrier and reduce tingling.

Every change in people's lifestyle will require a lot of practicality. Besides being valuable, green tea powder is also a practical product that can be used as a raw material for mixed foods and beverages that have market prospects, both locally and abroad. Basically, to produce green tea powder does not require complicated technology, and this technology has been available in Indonesia for ten years. Making green tea powder can be done simply through the process of steaming, drying, particle size reduction, and sifting until it reaches a certain particle size according to market needs.

Global consumers are increasingly paying attention to the nutrition, health, and quality of Green Tea Powder Products (Indrani and Mohanapriya, 2018). This statement is in line with Arifin, B., Suprihatini, R. (2013) almost 80 percent of the world's tea consumption is black tea but in recent years the interest in green tea has increased. Consumers are beginning to understand that their food choices can affect their health, and then they pay more attention to the health benefits of food in their efforts to maintain a healthy lifestyle (Goetzke et al., 2014 cit. Yang, J. M., Lee, J, 2020).

Green tea powder in Indonesia is defined as a dry powder produced by the processing of shoots and young leaves from the tea plant (Camellia sinensis) without going through a fermentation process (BSNI, 1998). Variation foods and beverage product enriched with green tea powder have been produced and widely used in West Java include: chocolate, pastries, cake, drinks, milk, and others.

\footnotetext{
*Corresponding author e-mail: lucy.trimo@gmail.com; lucyana.trimo@unpad.ac.id.
} 
The green tea had many health benefits; for example, the antioxidants lowered the risk of cancer, diabetes and obesity, etc. Mostafa (2014) says that the tea supported with catechin, drunk for many weeks, may be beneficial for people suffering from moderate diabetes or hyperlipidemia, reducing its complications such as liver and kidney disorders. The type of tea powder that is widely used in the food and beverage industry is green tea powder. The use of green tea powder has some benefits, especially on health. Raharjo et al. (2020) showed that the addition of green tea powder to wheat bread had a significant effect on increasing antioxidant activity. In line with the increasing attention of consumers towards healthy products, the preference of consumers to buy food and beverage containing green tea powder is also increased. The purpose of this study is to determine how consumers respond to food and beverages enriched with green tea powder, formulate marketing strategies, and develop the tea powder market. These findings have important implications for manufacturers, marketers and retailers in food and beverages product enriched with green tea powder, especially in Bandung city.

\section{Research Methods}

The research method used to evaluate consumer preferences for a variety of food and beverage products containing green tea powder was a positive approach and descriptive statistics. The research location was the city of Bandung which is considered as one of the world's creative cities famous for its food and beverages, apart from being the center of culinary tourism in West Java Province. Primary data and secondary data were used in this study. The method used in primary data collection was a descriptive survey using a well-structured questionnaire and interviews with 200 selected respondents. Respondents were selected using accidental sampling technique. The primary data collected were consumer characteristics, types of food and beverage products containing green tea powder purchased, consumer responses and opinions on the purchased product. Secondary data was collected from various sources, including the Central Statistics Agency, the Ministry of Trade, the Ministry of Industry, and the Central Statistics Agency for West Java. Testing the consumer's acceptability of various food and beverage products enriched with green tea powder was carried out using organoleptic tests. The organoleptic test carried out in this study was the hedonic test (preference test). In this test, researchers were asked to express their personal responses about their likes or dislikes and their level of preference for fineness, particle size, taste, aroma, shape and color, and price attributes. This level of preference is called the hedonic scale (Choi et al., 2002). The hedonic scale is then converted into a numerical scale with numerical quality according to the level of preference (Rahmi et al, 2013). The hedonic scale used was $1-5$, with $1=$ very like, $2=$ like, $3=$ neutral, $4=$ dislike, and $5=$ very dislike (SinghAckbarali and Maharaj, 2014).

The applied method is used to determine the attitudes of potential consumers towards tea powder products which are symbolically formulated as follows:

$$
\mathrm{AB}=\sum \mathrm{Wi}|\mathrm{Ii}-\mathrm{Ji}|
$$

Where $\mathrm{AB}$ is the respondent's attitude towards the product enriched with green tea powder, $\mathrm{W}_{\mathrm{i}}$ is the importance of attribute $\boldsymbol{i}$ to the product enriched with green tea powder, and $\mathrm{I}_{\mathrm{i}}$ is Ideal performance required by consumers in attribute $I, \mathrm{~J}_{\mathrm{i}}$ is trust regarding the actual performance of existing products and samples of products.

Numerical linear scale used are :

$0 \leq \mathrm{Ab}<\mathrm{x} \quad$ : very good

$\mathrm{x} \leq \mathrm{Ab}<2 \mathrm{x}$ : good

$2 \mathrm{x} \leq \mathrm{Ab}<3 \mathrm{x}$ : neutral

$3 \mathrm{x} \leq \mathrm{Ab}<4 \mathrm{x}$ : bad

$4 \mathrm{x} \leq \mathrm{Ab}<5 \mathrm{x}$ : very bad

\section{Results and Discussion}

\subsection{Characteristics of Consumers}

The characteristics of consumers West Java Typical food and beverages enriched with green tea powder can be seen from their age, education, and type of work. When viewed from the age distribution of consumption of typical foods and beverages of West Java made from green tea powder, most of them are under the age of 31-49 years (83\%) with the range between $19-50$ years old. This shows that they are in the productive age group and live in urban areas which usually have a high desire to always try new things.

The level of education also influences consumer choices in choosing food and beverage. Education describes how a person's knowledge about an object or phenomenon and can provide information for the person concerned. Furthermore, knowledge can be obtained through experience or interaction with other people. Experience provides an understanding of an object. The results of interactions with other people create a form of communication that contains messages, for example knowledge. Related to this research, education can influence a person in determining their choice of West Java food and beverages product made from green tea powder.

From the results of the study, it was found that 50 percent of education consumers were undergraduates. This is understandable because they generally live-in urban areas, have higher education and income, and have more opportunities and options to sample new foods and drinks. In addition, the ease and availability of new food and beverages are widely circulated in urban areas; in other words, urban areas, especially Bandung City, are one of the culinary centers in West Java. In the city of Bandung, there are many foods and beverages that have various innovations in taste, shape and size, as well as packaging. The high level of education possessed by consumers will affect the way of thinking in choosing the available food and drinks. Several factors that can influence them in choice include: taste, price, uniqueness of a product, packaging, convenience/availability, prestige, health, environmental considerations, and others. In addition, their average occupations are: self-employed, student, civil servant, pharmacist, designer, and civil servant, with these livelihoods representing different levels of income. The level of consumer income varies, causing different types of food and beverages purchased, depending on the level of income. 
3.2. Consumer Preference on West Java Type of Foods and Beverages Products Enriched with Green Tea Powder

The types of food product they like are: bakpia, pukis, block cake, mocha, brownies, chocolate, cake, martabak, donuts, banana nuggets, ice cream, cubit cakes, and toast, while the preferred green tea flavor drinks are: matcha, green tea milk, thai tea, greentea latte. Some of the foods that have been consumed by consumers and their opinions on these foods can be seen in Table 1(a\&b). Most consumers (97 percent) stated that Foods that are mixed with green tea have a fresh taste, are fragrant, and reduce sweetness, especially for chocolate, spongecake and dodol.

From the survey results on the taste preferences of culinary foods and typical souvenirs of West Java, it turns out that people in West Java prefer the taste of tea, so this is a potential for West Java as a center for tea producers in Indonesia and also to be able to develop a typical food and beverage industry made from tea. This is supported by a statement from Shen et.al. (2014) that the addition of green tea powder to these foods does not reduce the liking value based on sensory tests. The preference of consumers for the taste of food and souvenirs typical of West Java who like food and drinks with the taste of tea reached 53\% of respondents; the rest of respondents (47\%) still prefer non-tea flavors for various reasons as the price is more expensive, the size is smaller, and the texture is still not soft. For the typical West Java cake made with tea, it turns out that the cubit cake with green tea flavor is the most favorite choice in West Java (36\%), followed by brownies as a second choice (19\%). Lapis Bogor and green tea flavored bread each only occupy the favorite choices by $14 \%$ of all respondents, and other types of cakes by $17 \%$.

Consumer responses to green tea flavored mixed food and beverage are quite diverse. They expressed their liking for the product with various responses, that is: 1) delicious and fresh, 2) distinctive and unique taste, 3) add flavor, 4) the fragrance enhances the taste, 5) and beneficial for health. Furthermore, the response of consumers who stated that they did not like food and beverage mixed with green tea flavors, stated: 1) it caused an unpleasant taste, 2) the taste was less familiar, 3) did not like the smell, 3) it tasted strange, 4) did not like being mixed, 5) did not like the taste of green tea, and 6) Not all foods are suitable to be combined with green tea.
Table 1a. Consumer Opinion on Food Product Enriched with Green Tea Powder

\begin{tabular}{|c|c|}
\hline Kind of product & Consumer response \\
\hline \multicolumn{2}{|l|}{ Cake } \\
\hline Cubit & $\begin{array}{l}\text { The taste is delicious, the soft texture is } \\
\text { unique and varied }\end{array}$ \\
\hline Bakpia & Different and distinctive taste \\
\hline Pisang & The texture is soft and the taste is good \\
\hline Bread & The taste is delicious \\
\hline Pocky* & Aroma smell is good and taste is delicious \\
\hline Malkist* & The taste is delicious \\
\hline Kue balok & $\begin{array}{l}\text { It's a good mix, good created menu, and good } \\
\text { smells }\end{array}$ \\
\hline Dorayaki & The taste is delicious \\
\hline Donat & Appropiate combined of green tea taste \\
\hline \multicolumn{2}{|l|}{ Spongecake } \\
\hline Bolu susu & $\begin{array}{l}\text { Delicious, because the taste of green tea is } \\
\text { stronger }\end{array}$ \\
\hline Amanda* & $\begin{array}{l}\text { Soft texture and not too sweet (relative sweet), } \\
\text { unique and distinctive taste }\end{array}$ \\
\hline Bandung Makuta & Savory taste and delicious \\
\hline Cakenian & $\begin{array}{l}\text { Unique and delicious and more fragrant, the } \\
\text { green tea taste is not bitter }\end{array}$ \\
\hline Brownis kukus & $\begin{array}{l}\text { Delicious, the aroma of green tea causing a } \\
\text { fresh taste }\end{array}$ \\
\hline Sangkuriang* & $\begin{array}{l}\text { Green tea is soft, a perfect blend of cheese and } \\
\text { green tea is }\end{array}$ \\
\hline \multicolumn{2}{|l|}{ Coccolate } \\
\hline Kit Kat* & $\begin{array}{l}\text { The chocolate taste less sweet, a mix of } \\
\text { creamy chocolate and a distinctive matcha } \\
\text { aroma, the right combination }\end{array}$ \\
\hline Silverqueen* & $\begin{array}{l}\text { The green tea tastes just right, neither too } \\
\text { bitter nor too sweet }\end{array}$ \\
\hline Cadburry* & $\begin{array}{l}\text { The chocolate taste is soft because it is mixed } \\
\text { with green tea, and reduces the sweetness }\end{array}$ \\
\hline Delvi* & $\begin{array}{l}\text { Even though the tastes is bitter, but it still } \\
\text { delicious }\end{array}$ \\
\hline $\begin{array}{l}\text { Royce almond } \\
\text { matcha* }\end{array}$ & Delicious and not too sweet \\
\hline Hersey* & The taste is different from other product \\
\hline Dodol & $\begin{array}{l}\text { The taste is unique and the sweet taste is } \\
\text { reduces }\end{array}$ \\
\hline
\end{tabular}

Food mixed with green tea powder, according to some consumers (53 percent), has a fresh and fragrant taste and reduces sweetness, especially for the cubit cake, brownies, and Bogor layers cake. Furthermore, they also argue that beverage mixed with green tea can provide a refreshing taste and reduce sweetness (especially for dairy products), give a fragrant and healthy smell. Favorite beverages are: matcha, green milk tea, thai tea, green tea latte. In addition, they also rated not delicious taste to some types of drinks mixed with green tea, that are: coffee (strange taste), bandrek (strange taste), bajigur (strange taste), original green tea (it tastes bitter), and ocha (it tastes so bitter). 
Table 1b. Consumer Opinion on Food and Beverages Enriched with Green Tea Powder

\begin{tabular}{|c|c|}
\hline Product Type & Consumer Opinion \\
\hline Gomilk & Makes the sweet taste less dominant \\
\hline Chocolatos green tea & $\begin{array}{l}\text { Nice and fragrant taste and sweet taste } \\
\text { is not too dominant }\end{array}$ \\
\hline Milk & $\begin{array}{l}\text { The taste of milk is reduced if you add } \\
\text { green tea to make it more delicious, } \\
\text { refreshing. It tastes good when bought } \\
\text { warm, the taste is more varied, and is a } \\
\text { great combination, between milk and } \\
\text { green tea }\end{array}$ \\
\hline Green tea latte & $\begin{array}{l}\text { The taste is not too sweet, fresh and } \\
\text { smells like tea }\end{array}$ \\
\hline Thai tea green tea & $\begin{array}{l}\text { Tea mixed with milk is delicious, } \\
\text { refreshing, fragrant and delicious }\end{array}$ \\
\hline Matcha latte & $\begin{array}{l}\text { It's fresh, sweet, perfectly bitter, } \\
\text { themixture of milk and green tea is a } \\
\text { perfect match }\end{array}$ \\
\hline Green tea & The taste is unique and very refreshing \\
\hline Pure Green tea & $\begin{array}{l}\text { Can lower cholesterol levels and smell } \\
\text { good }\end{array}$ \\
\hline Green tea frappucino & Green tea taste decreased and less fresh \\
\hline Bajigur & The distinctive taste and aroma is lost. \\
\hline Bandrek & The distinctive taste and aroma is lost. \\
\hline
\end{tabular}

Furthermore, most consumers (76 percent) stated that drinks mixed with green tea can provide a refreshing taste and reduce sweetness (especially for dairy products), provide a fragrant and healthy aroma. The rest (24 percent) stated that coffee, bandrek and bajigur mixed with green tea tasted bad and strange.

Based on the description above, it can be concluded that product innovation among food and beverage producers has a different uniqueness and taste. However, it was found that 24 percent of consumers showed that mixed drinks with green tea powder did not always taste good and fresh, for example: coffee (strange taste), bandrek (strange taste), bajigur (strange taste), original green tea (it tastes bitter), and ocha (it tastes bitter). Generally, the consumer stated that the distinctive taste and aroma of Bajigur and Bandrek is lost. In addition, consumers also stated that foods and drinks with too much green tea taste will cause the bitter of green tea taste in product. Based on research of Phongnarisorn et al. (2018), it can be seen that matcha green tea powder (MGTP) is made with finely ground green tea leaves that are rich in phytochemicals, most particularly catechins. Catechins are the main polyphenols found in green tea. The content of catechins is what causes food and drinks to be fresh as well as the Acute Metabolic Response.

In order to improve food and beverage products typical of West Java made from tea as a favorite food in West Java and to support the tourism industry, there are several suggestions from respondents for improvement the quality of food and beverages product enriched with green tea powder. Consumer suggestions to food and beverages product enriched with green tea powder can be seen in the following figure 1 :

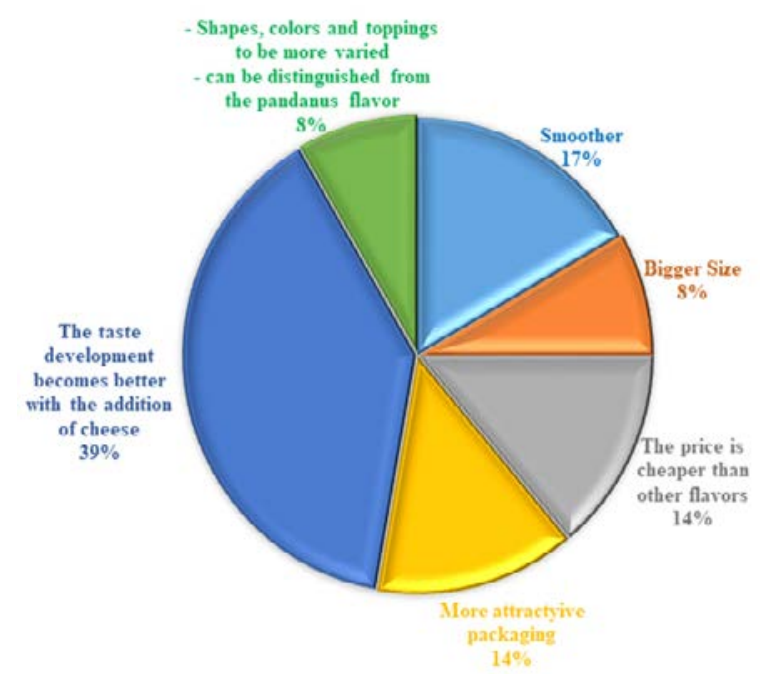

Figure 1. Consumers Suggestions for improvement of West Java typical food and beverages enriched with green tea powder

The first priority suggestion is to improve the taste to make it better, that is by reducing the bitterness and it should be for food combined with cheese (39\%) to make it savorer and more delicious. The second and third places are texture refinement to make it softer and tastier, as well as the price attribute. Yang and Lee (2020) stated it is important that new products have competitive sensory quality and that production is economically viable for the local community. This improvement product is very important, because the design of the innovated product has powerful impact on consumer attention (Mahir, 2020)

The price of green tea-flavored cakes is more expensive than other cake flavors because it will cause them to be unable to compete in the market with other food products that are not made from green tea. According to Kiranmayi (2017), the price plays an important factor for the customer. The customer prefers to shop the product with cheap prices. The price and promotion have the strongest impact on consumer acceptance and buying decisions (Melovic et al., 2020). According to Hugar and Patil (2017), discounts and gifts given, such as buy one get one, greatly influenced the consumer preferences. The final consumers' opinion regarding food and beverage products is that the packaging and presentation of the taste of the product are made more attractive and varied. In addition, consumers also want packaging that is environmentally friendly, such as paper bags (easy to recycle), unique shapes, and clear images or photos of green tea (leaves and powder) on the label. Availability of Food and Beverages Products Enriched with Green Tea Powder

Availability and convenience for consumers to get food made from green tea powder are crucial for consumers to buy it. Furthermore, for novice consumers this convenience will encourage them to be willing and interested to try it. The above conditions are shown by the results of this study that more than half of the consumers studied (58.20 percent) stated that it was easy to obtain food made from green tea powder in Bandung. Furthermore, they also stated that there are various kinds of food made from green tea powder both in form and taste. They can easily find places to buy green tea powder at: UKM exhibition stands, cafes, shops, canteens, stalls, 
and also in mini markets or super-markets around Bandung.

The marketing strategies like product, price, promotion, place, process, people and physical evidence play a significant role in assuring a success and sizable profits for the companies. On the other hand, customers face several problems such as delay in product supplies, unfair and discriminated prices, and lack of information about expired and obsolete products, deceptive advertisements, raising customer complaints, unsociable approach of sales force, reduced sales after service, etc. These problems potent to increase customer's dissatisfaction..

\subsection{Preference of West Java Typical Food Products} Based on Green Tea Powder from the producer Side

The results of the analysis of the preferences for food and beverage products containing green tea powder in terms of food and beverage producers, namely by using the multi-attribute ideal number which are similar to the Semantic Differential method (Kotler, 1993) seen in Table 2. In Table 2, it can be seen that the attributes of food and beverages that have the highest weight are taste criteria, which are then followed respectively by aroma and particle fineness criteria. Furthermore, price is the attribute with the lowest level of importance (rank five). This result is in line with Chueamchaitrakun et al. (2018), that Indonesian people considered color, flavor and taste as key attributes affecting purchase.

Table 2. The Results Preference Analysis of Food and Beverages Product Contain Green Tea Powder

\begin{tabular}{|c|c|c|c|c|c|c|c|c|}
\hline Attributes & Weight & Ideal & Brownies & Bread & Layer Cake & Cubit Cake & Coffee & Tea Latte \\
\hline Particle size fineness & 0,13 & 5 & 4 & 5 & 4 & 3 & 4 & 3 \\
\hline Taste & 0,31 & 5 & 3 & 4 & 2 & 3 & 4 & 3 \\
\hline Aroma & 0,25 & 5 & 5 & 5 & 4 & 3 & 4 & 3 \\
\hline Shape and Color & 0,24 & 5 & 5 & 5 & 4 & 4 & 4 & 3 \\
\hline Price & 0,07 & 3 & 4 & 3 & 4 & 5 & 3 & 4 \\
\hline \multicolumn{3}{|c|}{ Value of product attitude } & 0,68 & 0,31 & 1,48 & 1,48 & 0,93 & 1,79 \\
\hline \multicolumn{3}{|c|}{ Product Refinement Priorities } & 4 & 5 & 2 & 2 & 3 & 1 \\
\hline \multicolumn{4}{|c|}{$\begin{array}{l}\text { Based on the Semantic Differential method, if the } \\
\text { calculation results obtained are closer to zero then closer to } \\
\text { ideal preference. This means that refinement of particle } \\
\text { size attribute, taste, aroma, color, and price are getting } \\
\text { closer to zero, the food and beverages products based on } \\
\text { green tea flour are increasingly accepted and liked by } \\
\text { consumers. Meanwhile, the value of the tea latte showed } \\
\text { that it was far above zero, that is } 1.79 \text {, and it was far from } \\
\text { the ideal value. This condition is also experienced by kue } \\
\text { cubit and lapis bogor, which have the same value, } 1.48 \text {. } \\
\text { Only bread has a value close to zero, that is } 0.31 \text {. It means } \\
\text { that only bread which has high preference and great } \\
\text { demand and purchased by consumers, then followed by } \\
\text { brownies which have value of } 0.68 \text {. The ranking order for } \\
\text { product refinement to fulfil the needs of the food and } \\
\text { beverage producers, starting from priorities requiring }\end{array}$} & \multicolumn{5}{|c|}{$\begin{array}{l}\text { unique taste and are different from others, food and } \\
\text { beverage producers often forget the local specialties, such } \\
\text { as Bandrek and Bajigur.. The distinctive taste and aroma } \\
\text { of Bajigur and Bandrek is lost. In addition, consumers also } \\
\text { claim that foods and drinks that taste too much of green tea } \\
\text { will cause a bitter taste of green tea to appear. } \\
\text { In order to increase the consumer preferences on foods } \\
\text { and beverages product enriched with green tea powder- } \\
\text { based, food and beverages manufacturer must improve the } \\
\text { product, especially in 1) the combination must be right so } \\
\text { that the bitterness is lost, 2) texture of food product } \\
\text { become more softer and tastier, 3) the price of green tea } \\
\text { flavored cakes is cheaper than non-tea taste, 4) the } \\
\text { packaging views more attractive and good looking, 5) use } \\
\text { environmentally friendly packaging, 6) create the } \\
\text { uniqueness of product. }\end{array}$} \\
\hline
\end{tabular}
immediate improvement, was the tea latte, lapis Bogor and pinch cake, coffee; brownish, and bread.

Food and beverage producer also must prioritize these four criteria (taste, aroma, shape and color, and particle fineness) because they can affect the quality of their products. This is not a difficult thing because food and beverage producers are always accustomed to pursuing consumer tastes and needs. This result corresponds to Mahir (2020), i.e. that the design of the innovated product has powerful impact on consumer attention

\section{Conclusions And Suggestions}

The results showed that respondents (53\%) preferred the taste of green tea. Green tea-based product of foods and beverages that were preferred by consumers are cubit cakes, brownies, Bogor layers cake, bread, and others. Consumers' favorite beverages are matcha, green tea milk, and green tea latte, while favorite food are bread and brownies. In innovating to produce products that have a

\section{Acknowledgments}

Finally, we would like to thank the DRPMI (Directorate of Research and Community Service for Innovation) Padjadjaran University for funding and supporting us in conducting this research, through the ALG (Academic Leadership Grant) scheme with contract number 1427 / UN6.3.1/ LT / 2020, and also I would like to thank to the anonymous reviewers who have offered helpful suggestions.

\section{References}

Rahmi, A, Susi, Agustina L. 2013. Anlisi tingkat kesukaan konsumen, penetapan umur simpad, nanalisia kelayakan usaha dodol pisang awa. Ziraa'ah., 37(2): 26-32.

Arifin, B., Suprihatini, R. 2013. Rapid Appraisal of Indonesian Tea Value Chains. Research Report prepared for the World Bank. BSNI (Badan Standar Nasional Indoneia). 1998. Standard of Green tea powder, SNI-01-4453-1998. 
Campbell, E.L., Chebib, M., Johnston, G.A. 2004. The dietary flavonoids apigenin and (-)-epigallocatechin gallate enhance the positive modulation by diazepam of the activation by GABA of recombinant GABA(A) receptors. Biochem. Pharmacol.(68): 1631-1638.

Choi, J.Y., Park, C.S. Kim, D.J., Cho, M.H., . Jin, B.K, Pie. J.E., Chung, W.G. 2002.Prevention of nitric oxide-mediated 1-methyl4-phenyl-1, 2,3,6 tetrahydro-pyridineinduced Parkinson's disease in mice by tea phenolic epigallocatechin 3-gallate. Neurotoxicology; 23: 367-374.

Chueamchaitrakun, P., Adawiyah D. R, Prinyawiwatkul, W. 2018. Understanding Indonesian People: Consumer Acceptance and Emotions Study of Green Tea Products from Thailand. CAST, 18 (1): 37-44.

Engel, J.F., Blackwell, R.D, Miniard, P.W. 1990. Consumer Behavior, Sixth Edition. The Dryden Press. Illinois. 789 pp

Frei, B., Higdon, J.V. 2003. Antioxidant activity of tea polyphenols in vivo: evidence from animal studies. J. Nutr.(133):3275S-3284S.

Hantraye, P., Brouillet, E. Ferrante, R., Palfi, S., R. Dolan, R.T. Matthews, R.T., Beal, M.F.. 1996. Inhibition of neuronal nitric oxide synthase prevents MPTP-induced parkinsonism in baboons. Nat. Med. 2: 1017-1021.

Hara, Y. 2001. Green tea : health benefits and applications. Marcel Dekker, Inc.New York.. pp

Hassan, S.M.A. 2020. Anti-inflammatory and Anti-proliferative Activity of Coconut Oil against Adverse Effects of UVB on Skin of Albino Mice. Jordan Journal of Biological Sciences (JJBS). 15(3): $295-303$

Ho, C.T., Lin, J.K., Shahidi, F.. 2008. Tea and tea products : chemistry and health-promoting properties. Boca Raton, Florida: CRC Press. .

Hugar, G., Patil, M. R. 2017.Customer Behavior Analysis towards Select Fast Moving Consumer Goods with Special Reference to Branded Tea Powder Products: Empirical Study from Mumbai City. Imperial Journal of Interdisciplinary Research (IJIR) Vol-3, Issue-1: 1226-1236.

Indrani, G, Mohanapriya, T..2018. A Study on Customers Perception and Satisfaction towards Green Tea with Specia Reference to Coimbotore City. International Journal of Business and Management Invention (IJBMI) .,7(3) : 25-28

Kimura, K.,. Ozeki, M., Juneja, L.R., Ohira, H. 2007.L-Theanine reduces psychological and physiological stress responses. Biol. Psychol. (74): 39-45.

Kiranmayi, N. 2017. Factors Affecting the Consumer Behavior with Reference to Select FMCG Retail Outlets. International Journal of Creative Research Thoughts(IJCRT): 32-334.
Kotler, P. 1993. ManajemenPemasaran. Analisa, Perencanaan, Implementasi, dan Pengendalian. Terjemahan A. Zakaria Afiff. Lembaga Penerbit Fakultas Ekonomi Universitas Indonesia.

Lu, T.M,...Lee, C.C., Mau, J. L., Lin. S.D. 2010. Quality and antioxidant property of green tea sponge cake. Food Chemistry. 119(3): 1090-1095.

Maeda-Yamamoto, M., Ema, K., Tokuda, Y., Monobe, M., Tachibana, H. Sameshima, Y., Kuriyama, S. 2014. Effect of green tea powder (Camellia sinensisL. cv.Benifuuki) particle size on o-methylated EGCG absorption in rats; The Kakegawa Study. Cytotechnology: 171-179.

Mahir, A. M.. 2020. The Impact of Product Innovation on Consumer Behavior in Food Sector of Azerbaijan. Dissertant of Baku Engineering University. No. 12: 203-207.

McKinley, H., Jamieson, M. 2009. Handbook of green tea and health research. New York: Nova Science Publishers, Inc.

Melovic, B., Cirovic, D., Dudic,V, Vulic, T. B, Gregus, M. 2020. The Analysis of Marketing Factors Influencing Consumers' Preferences and Acceptance of Organic Food ProductsRecommendations for the Optimization of the Offer in a Developing Market. Foods 2020, 9, 259: 1-23

Mostafa, U. El-Sayed. 2014. Sciences Effect of Green Tea and Green Tea Rich with Catechin on Blood Glucose Levels, Serum Lipid Profile and Liver and Kidney Functions in Diabetic Rats. Jordan Journal of Biological (JJBS). 7(1): 7 - 12. Phongnarisorn, B., Orfila, C., Holmes, M., Marshall, L. J.2018. Enrichment of Biscuits with Matcha Green Tea Powder: Its Impact on Consumer Acceptability and Acute Metabolic Response. Foods. 7, 17: pp. 15 PPTK. 2008. PetunjukTeknisPengolahanTeh. Bandung: Pusat Penelitian The dan Kina.

Rahardjo, M., Wahyu, F. D., Nadia, T. 2020. Karakteristik Fisik, Sensori, Serta Aktivitas Antioksidan Roti Gandum dengan Tambahan Serbuk Teh Hijau. Jurnal Pangan dan Agroindustri. 8(1): 47-55

Shen, X. J., Han, J.Y. , Ryu, G. H. 2014. Effects of the addition of green tea powder on the quality and antioxidant properties of vacuum-puffed and deep-fried Yukwa (rice snacks). LWT - Food Science and Technology 2014.; 55(1): 362-367.

Singh-Ackbarali, D., Maharaj, R. 214. Sensory Evaluation as a Tool in Determining Acceptability of Innovative Products Developed by Undergraduate Students in Food Science and Technology at The University of Trinidad and Tobago. Journal of Curriculum and Teaching., 3(1): 10-27.

Yang, J. M., Lee, J. 2020. Consumer perception and liking, and sensory characteristics of blended teas. Food Sci Biotechnol. 29(1): 63-74. 